\title{
Changes from Enkephalin-like to Gastrin/Cholecystokinin-like Immunoreactivity in Snail Neurons ${ }^{1}$
}

\author{
B. PETRICS GESSER AND L. -I. LARSSON ${ }^{2}$ \\ Unit of Histochemistry, University Institute of Pathology, Frederik den V's vej 11, DK-2100 Copenhagen $\varnothing$, Denmark
}

\begin{abstract}
Coexistence of regulatory peptides is reported with increasing frequency in the mammalian neuroendocrine system. We have investigated the possible presence of such coexistence in the invertebrate Lymnaea stagnalis and have found evidence for concurrence of enkephalin- and gastrin/ cholecystokinin (CCK)-like peptides in identified neurosecretory neurons. Our immunocytochemical studies reveal, however, that some of these neurons show variations in their content of immunoreactive peptides depending upon season or age. Thus, the light green cells of the Lymnaea cerebral ganglion, known to produce a body growth-stimulating hormone, contain enkephalin-like immunoreactivity during spring and gastrin/CCK-like immunoreactivity during fall. During winter, these cells contain both enkephalin-like and gastrin/CCK-like immunoreactivities. In another group of neurosecretory neurons, the caudodorsal cells, known to produce an ovulation hormone, age-dependent changes were noted. Thus, in young animals, these cells contain enkephalin-like immunoreactivity; in animals of intermediate age, they contain both enkephalin- and gastrin/CCK-like immunoreactivity and, in older animals, only gastrin/CCK-like immunoreactivity can be detected in these cells. Interestingly, the mediodorsal bodies, which are endocrine organs also implicated in regulating sexual function of Lymnaea, show agedependent variations in immunocytochemically detectable enkephalin- and gastrin/CCK-like immunoreactivity which parallels that found in the caudodorsal cells. The changes noted in the light green cells and the caudodorsal cells are detected both in the cell bodies and in the terminals of these cells, suggesting that the immunoreactivity represents secretory material. The relation, if any, between the immunoreactivities detected and the growth and reproduction of Lymnaea remains to be established, as do the factors responsible for the observed age- and season-dependent variations.
\end{abstract}

Received April 11, 1984; Revised October 8, 1984;

Accepted November 9, 1984.

\footnotetext{
${ }^{1}$ Antisera 4562 and 4698 were kindly donated by Professor J. F. Rehfeld, Department of Clinical Chemistry, Rigshospitalet, Copenhagen, and antisera $L_{2}$ and $M_{14}$ were donated by Professor $S$. $H$. Snyder, Department of Neuroscience, Johns Hopkins Medical School, Baltimore, MD. Highly purified porcine GIP was donated by Dr. A. Moody, Novo Research Institute, Bagsværd, Denmark, and cholecystokinin-33 (99\% pure) was donated by Professor V. Mutt, Department of Chemistry, Karolinska Institutet, Stockholm, Sweden. Excellent technical assistance was given by Mrs. J. B. Lauridsen and $\mathrm{K}$. Høgenhaven. The Unit of Histochemistry is sponsored by the Danish Medical Research Council and the Danish Cancer Society.

${ }^{2}$ To whom correspondence should be addressed.
}

In the mammalian neuroendocrine system, there is mounting evidence for colocalization and cosecretion of biologically active peptides (for reviews, see Hökfelt et al., 1980; Larsson, 1980; Snyder, 1980). In some cell systems, like the pituitary corticotrophs and melanotrophs, coexistence of ACTH, $\alpha$-melanocyte-stimulating hormone, and $\beta$-endorphin is explained by the synthesis of a common large precursor containing multiple active peptide sequences that can be released through limited intracellular proteolysis and processing (see Eipper and Mains, 1978, for review). Other examples of colocalization, notably those of calcitonin and somatostatin in thyroid parafollicular cells, gastrin and ACTH-related peptides in pituitary and gastrointestinal endocrine cells, and cholecystokinin, enkephalins, and oxytocin in neuroendocrine neurons, are not explained through a common precursor, however (Buffa et al., 1979; Larsson, 1981a, 1985; Larsson and Rehfeld, 1981; Goodman et al., 1982; Vanderhaeghen et al., 1983; Kameda et al., 1984). Interestingly, in many of the latter systems, variations in peptide content during ontogeny has been noted (Larsson and Mørch-Jørgensen, 1978; Kameda et al., 1984; Larsson, 1985). Whether this relates to differences in synthesis, uptake, or release of the peptides detected can only be solved through in situ hybridization techniques. Nevertheless, these findings indicate that the peptide repertoire of endocrine cells may show nonparallel variations. The factors responsible for these variations and their physiological importance are unknown.

We were interested in studying the occurrence and concurrence of peptides in lower species, as it was hoped that simple changes in the environment would elicit changes in immunoreactive peptides in neuroendocrine cell types. We selected the freshwater snail Lymnaea stagnalis for this work. The anatomy of the neuroendocrine cell system in the brain of this species has been extremely well studied, and two groups of neurendocrine cells in the cerebral ganglion, the caudodorsal cells $(C D C)^{3}$ and the light green cells (LGC), have been found to produce an ovulation hormone and a body-growth-stimulating hormone, respectively. The two groups of LGC occurring in the Lymnaea cerebral ganglion are associated with the medial and lateral dorsal bodies (MDB and LDB), respectively (Joosse, 1964; Wendelaar Bonga, 1970; Gerærts, 1976; Gerærts and Bohlken, 1976; Roubos et al., 1976). Annual activity changes in all of these structures have previously been reported by Joosse (1964) using histological stains for neurosecretory material. Moreover, a fair amount of immunocytochemical work has been carried out in Lymnaea stagnalis, resulting in the identification of many different peptide immunoreactivities (Schot et al., 1981; Schot and Boer, 1982). We therefore selected this species for study in an attempt to look for coexistence of peptide immunoreactivities in the

\footnotetext{
${ }^{3}$ Abbreviations used in the text are: $\mathrm{BGC}$, bright green cells; $\mathrm{CC}$, cerebral commissure; CCK, cholecystokinin; CDC, caudodorsal cells; LDB, laterodorsal body; LGC, light green cells; MDB, mediodorsal body; MLN, median lip nerve; NHA, neurohaemal area
} 
cerebral ganglion and to see whether age or seasonal variations occurred.

\section{Materials and Methods}

Specimens of Lymnaea stagnalis (shell height, 37 to $52 \mathrm{~mm}$ ) were collected in a local pond during spring, fall, and winter. The size of the snails was moasured from the apex to the front edge of the helix. The material comprised a total of 21 animals, divided in size groups, as illustrated in Table 1. Of these snails, nine were collected in spring (March to June), nine in fall (Seplernber lo November), and three in winter (January). After decapitation, the nervous system was dissected out and fixed in $4 \%$ paraformaldehyde in $0.1 \mathrm{M}$ sodium phosphate buffer, $\mathrm{pH} 7.3$, overnight at $4^{\circ} \mathrm{C}$ for cryostat sectioning as described (Larsson, 1981b). Adjacent sections, $7 \mu \mathrm{m}$ thick, from spring, fall, and winter snails were immunocytochemically stained. As the diameters of the LGC were between 40 and $60 \mu \mathrm{m}$ and those of the CDC were slightly larger $(50$ to $70 \mu \mathrm{m})$, most cells were represented in several adjacent sections. Staining for enkephalin-like immunoreactivity em-

\section{TABLE I}

Age/size-dependent changes from enkephalin-like (ENK) to gastrin/ CCK-like (CCK) immunoreactivities in Lymnaea stagnalis MDD, CDC, and terminals at the periphery of the CC

\begin{tabular}{|c|c|c|c|c|c|c|c|c|}
\hline & \multicolumn{2}{|c|}{$\begin{array}{c}37-39 \mathrm{~mm} \\
(n=7)\end{array}$} & \multicolumn{2}{|c|}{$\begin{array}{c}40-41 \mathrm{~mm} \\
(n=4)\end{array}$} & \multicolumn{2}{|c|}{$\begin{array}{c}42-48 \mathrm{~mm} \\
(n=8)\end{array}$} & \multicolumn{2}{|c|}{$\begin{array}{c}49-52 \mathrm{~mm} \\
(n=2)\end{array}$} \\
\hline & ENK & CCK & ENK & CCK & ENK & CCK & ENK & CCK \\
\hline \multicolumn{9}{|l|}{ MDB } \\
\hline $\begin{array}{l}\text { Cortex } \\
\text { Medulla }\end{array}$ & $+^{a}$ & - & + & + & + & + & + & + \\
\hline $\mathrm{CDC}$ & + & - & + & + & - & + & - & + \\
\hline $\mathrm{CC}$ & + & - & + & + & - & + & - & + \\
\hline
\end{tabular}

${ }^{a}+$ denotes presence of immunoreactivity - denotes absence of immunoreactivity. ployed $\mathrm{Ab} . \mathrm{KA}_{3}$ and, for gastrin/CCK immunoreactivity, it employed $\mathrm{Ab}$. 4562. The specificities of these antisera have been detailed previously (Larsson and Rehfeld, 19821; Larsson and Stengaard-Pedersen, 1982). Briefly, $A b . K_{3}$, raised in a rabbit against synthetic Met-enkephalin, recog. nizes both Met- and Leu-enkephalin as well as the related molecules $\alpha-, \beta$-, and $\gamma$-endorphin and dynorphin (Larsson and Stengaard-Pedersen, 1982); Ab. 4562, raised in a rabbit against synthetic human gastrin I, recognizes the C-terminal tetrapeptide portion common to gastrin, cholecystokinin, and caerulein (Larsson and Rehfeld, 1981). Supplementary staining experiments were performed with Ab. 4698 (preabsorbed with $5 \mu \mathrm{g} / \mathrm{ml}$ of gastric inhibitory polypeptide), shown previously to be specific for the $\mathrm{N}$-terminal tetrapeptide portion of octapeptide cholecystokinin (Larsson and Rehfeld, 1977); with the oxidation- $L_{2}$ sequence selectively detecting Leu-enkephalin, $\alpha$-neoendorphin. and dynorphin; and with Leu-enkephalin-Sepharose preabsorbed antiserum $\mathrm{M}_{14}$ detecting Met- but not Leu-enkephalin congeners (details in Larsson and Stengaard-Pedersen, 1982). The antisera were applied at their optimal dilutions for $20 \mathrm{hr}$ at $4^{\circ} \mathrm{C}$, and the site of antigen-antibody reaction demonstrated by indirect immunofluorescence or by the peroxidase-antiperoxidase method (Larsson, 1981b; Sternberger, 1974). Controls included conventional staining controls as recommended (Larsson, 1981b; Sternberger, 1974), as well as specificity controls using absorptions of antisera against Sepharose 4Bcoupled related and unrelated peptides. The peptides include: porcine cholecystokinin-33, synthetic human gastrin I, synthetic Met- and Leu-enkephalin, synthetic $\alpha$-endorphin, synthetic tetragastrin, and octapeptide cholecystokinin (CCK-8) (Peninsula Laboratories). All staining to be reported below is specific according to these criteria.

\section{Results}

The cerebral ganglion of the hermaphroditic Lymnaca stagnalis contains three main groups of neurosecretory cells: (1) light green cells (LGC) with terminals chiefly ending in the peripheral (neurohaemal) area of the median lip nerve (MLN) and considered to produce a body growth-stimulating hormone; (2) caudodorsal cells (CDC) with terminals in the peripheral (neurohaemal) part of the cerebral
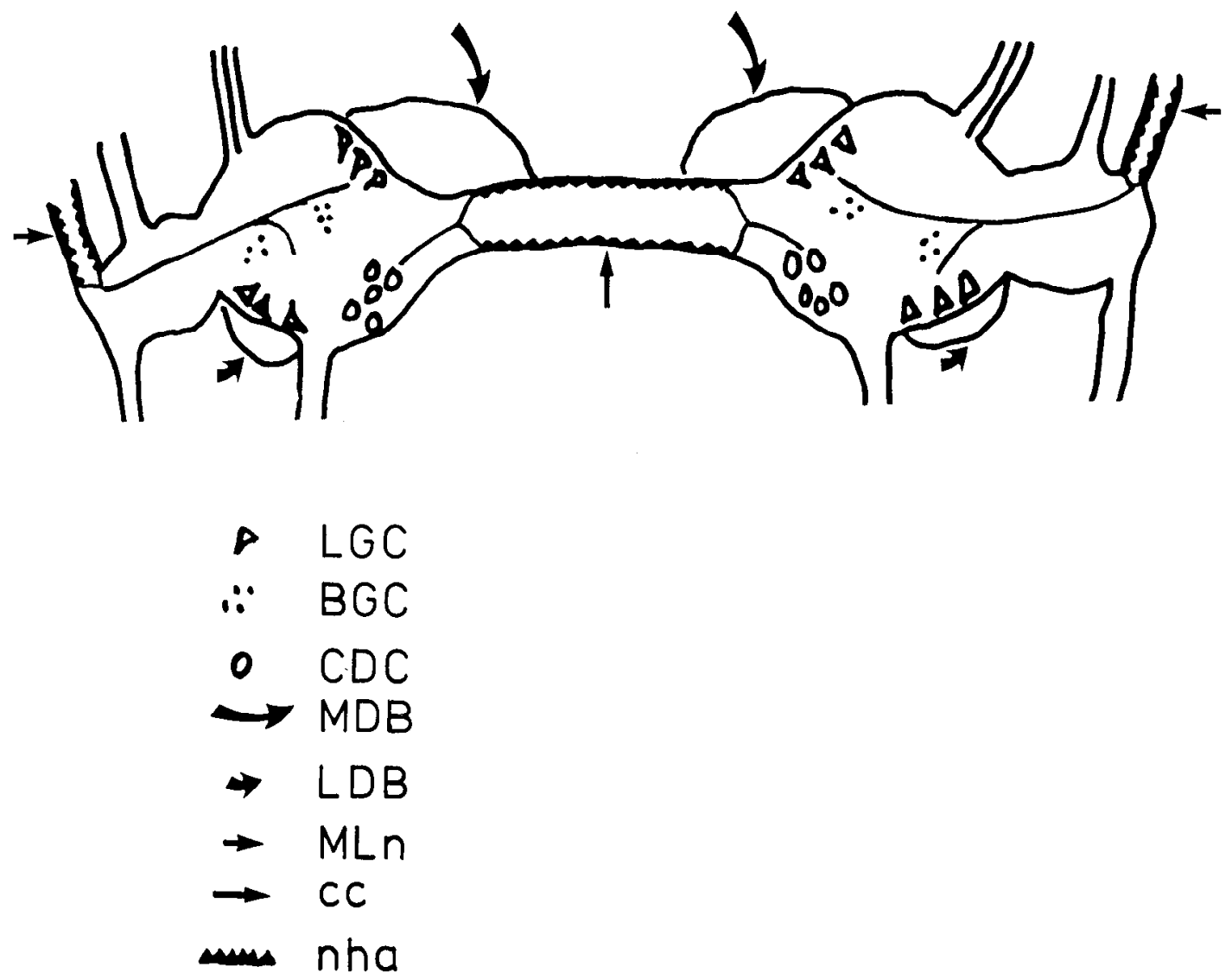

Figure 1. Schematic drawing illustrating the cerebral ganglion of Lymnaea stagnalis as modified from Wendelaar Bonga (1970). The dark stained areas at the periphery of the CC and MLN illustrate the neurohaemal areas of these structures. Note the close association of the two LGC groups with the MDB and $L D B$, respectively. 


\section{ENK}
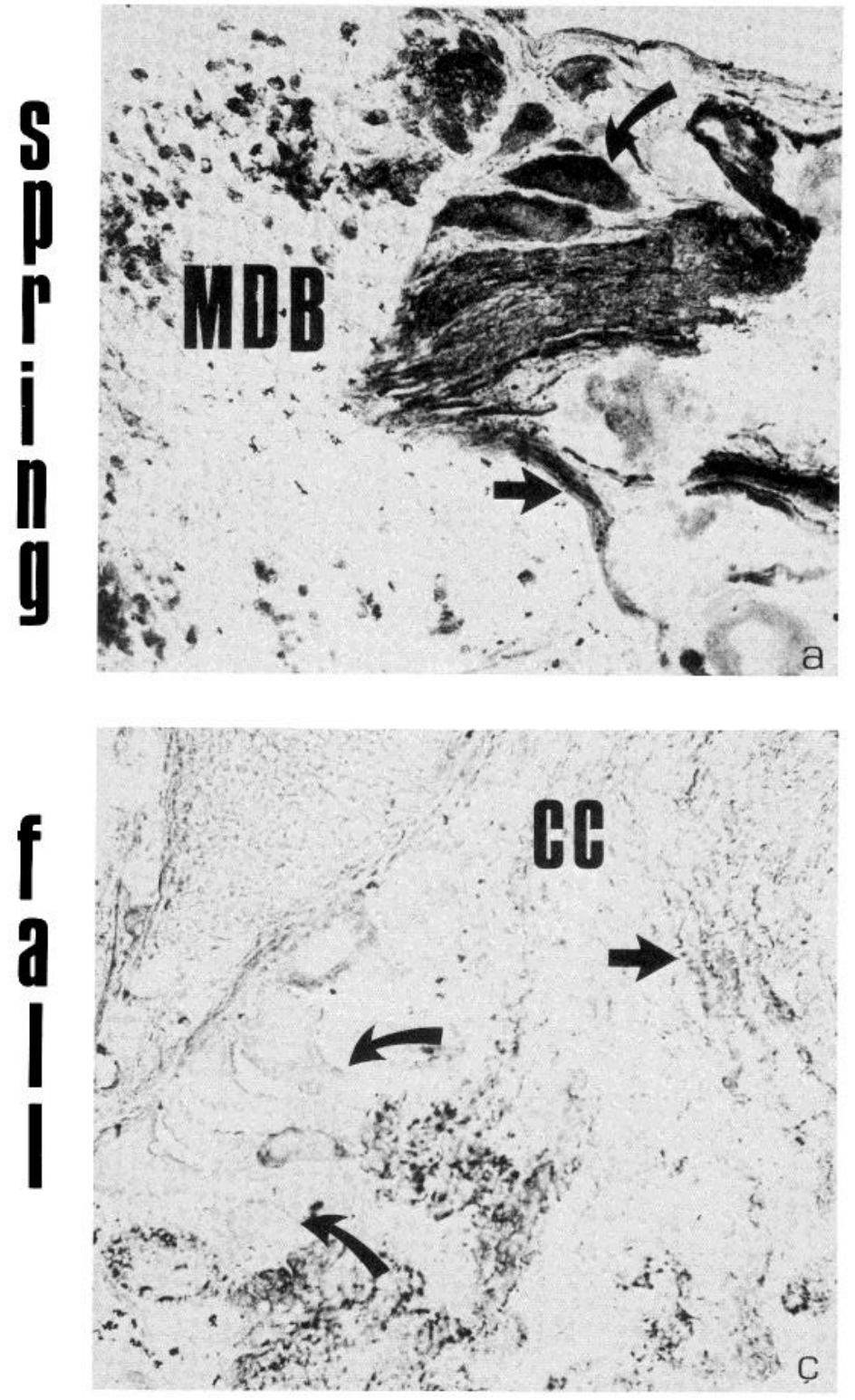

\section{CCK}
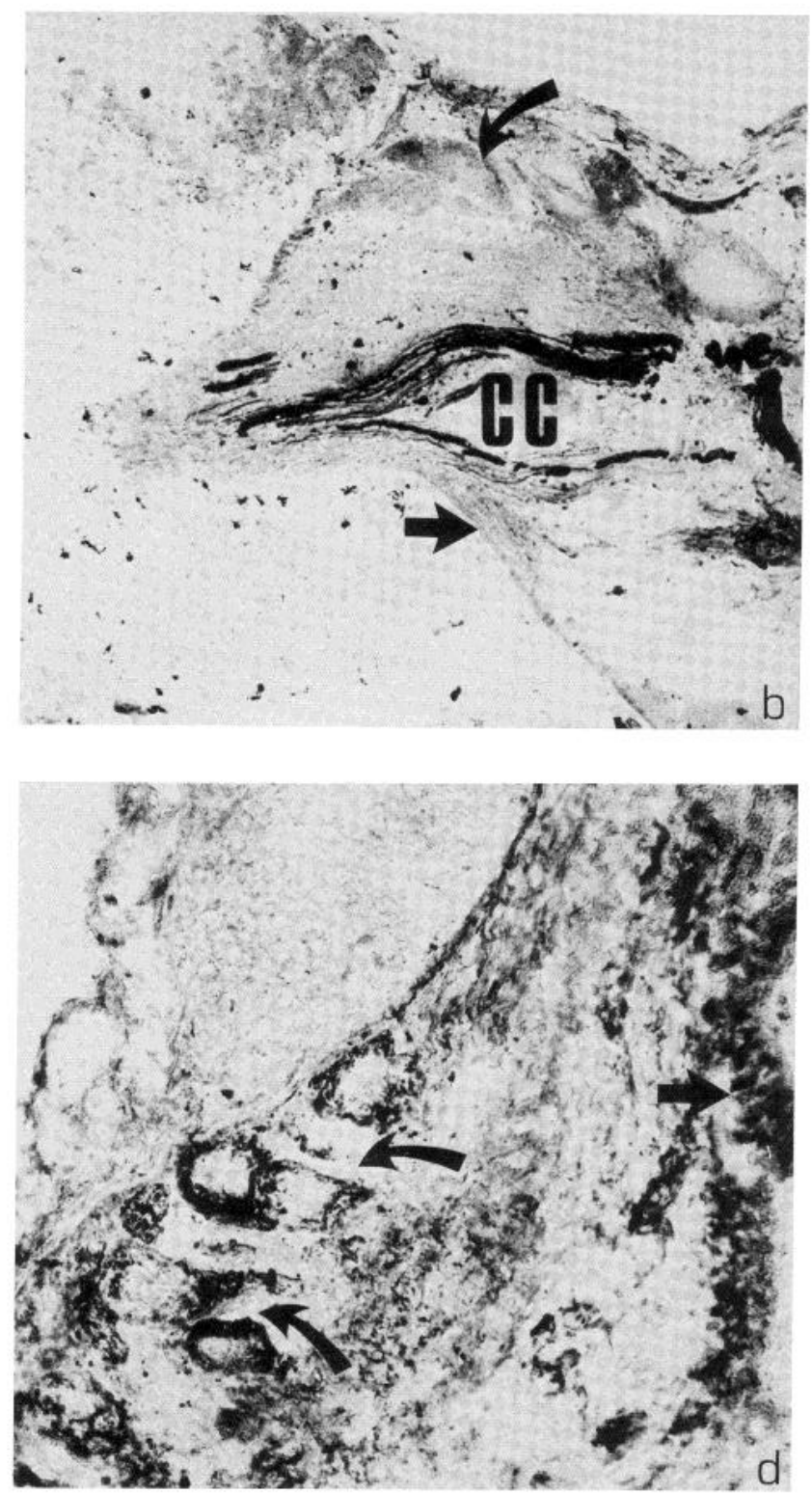

Figure 2. Adjacent sections of the cerebral ganglion of Lymnaea stagnalis. The LGC (curved arrow), the endocrine cells of the cortex of the MDB, and the terminals of the caudodorsal cells (straight arrow) at the periphery of the CC show variations in their content of enkephalin (ENK)- (a and $c$ ) and gastrin/ CCK $(b$ and $d)$-immunoreactive peptides during spring $(a$ and $b)$ and fall $(c$ and $d)$. Note that during spring, the LGC are strongly immunoreactive for enkephalin, whereas during fall, these cells are strongly immunoreactive for gastrin/CCK. Magnification $\times 256$.

commissure (CC) and considered to produce hormone(s) influencing ovulation; and (3) bright green cells (BGC) with yet unknown functions (Joosse, 1964, 1975; Wendelaar Bonga, 1970; Gerærts, 1976; Gerærts and Bohlken, 1976; Roubos et al., 1976) (Fig. 1). The LGC are divided into two groups which are closely associated with the medio- and latero-dorsal bodies (MDB and LDB), respectively. The MDB and LDB are glandular structures attached to the cerebral ganglion and are supposed to control vitellogenesis.

Staining of cerebral ganglia from snails captured during spring revealed strong enkephalin-like immunoreactivity $\left(\mathrm{Ab} . \mathrm{KA}_{3}\right)$ in nerve cell bodies belonging to both groups of LGC (Fig. 2). In addition, numerous terminals in the peripheral part of the MLN (corresponding to the known terminations of the LGC) were heavily stained during spring. In addition to these cells and terminals, enkephalin-like immunoreactivity was also detected in the CDC (see below) and in a portion of the BGC, cells in the anterior and ventral lobes of the cerebral ganglia, and in nerve fibers scattered in the ganglion and also running centrally in the CC and the MLN. Staining of cerebral ganglia from snails captured during fall with $\mathrm{Ab} . \mathrm{KA}_{3}$ revealed no reaction in the LGC or in terminals located peripherally in the MLN. In contrast, staining of the BGC, the cells of the anterior and ventral lobe of the cerebral ganglia, and the fibers running centrally in the $\mathrm{CC}$ and MLN was identical to that obtained in spring snails. That the absence of staining of the LGC and the peripheral terminals of the MLN in fall snails was not due to methodological variation was shown by staining sections from spring and fall snails in parallel and by the unchanged staining of several other cell and fiber groups referred to above.

Staining of fall snails for gastrin/CCK-like immunoreactivity (Ab. 4562) revealed strong staining of the LGC and of terminals located 

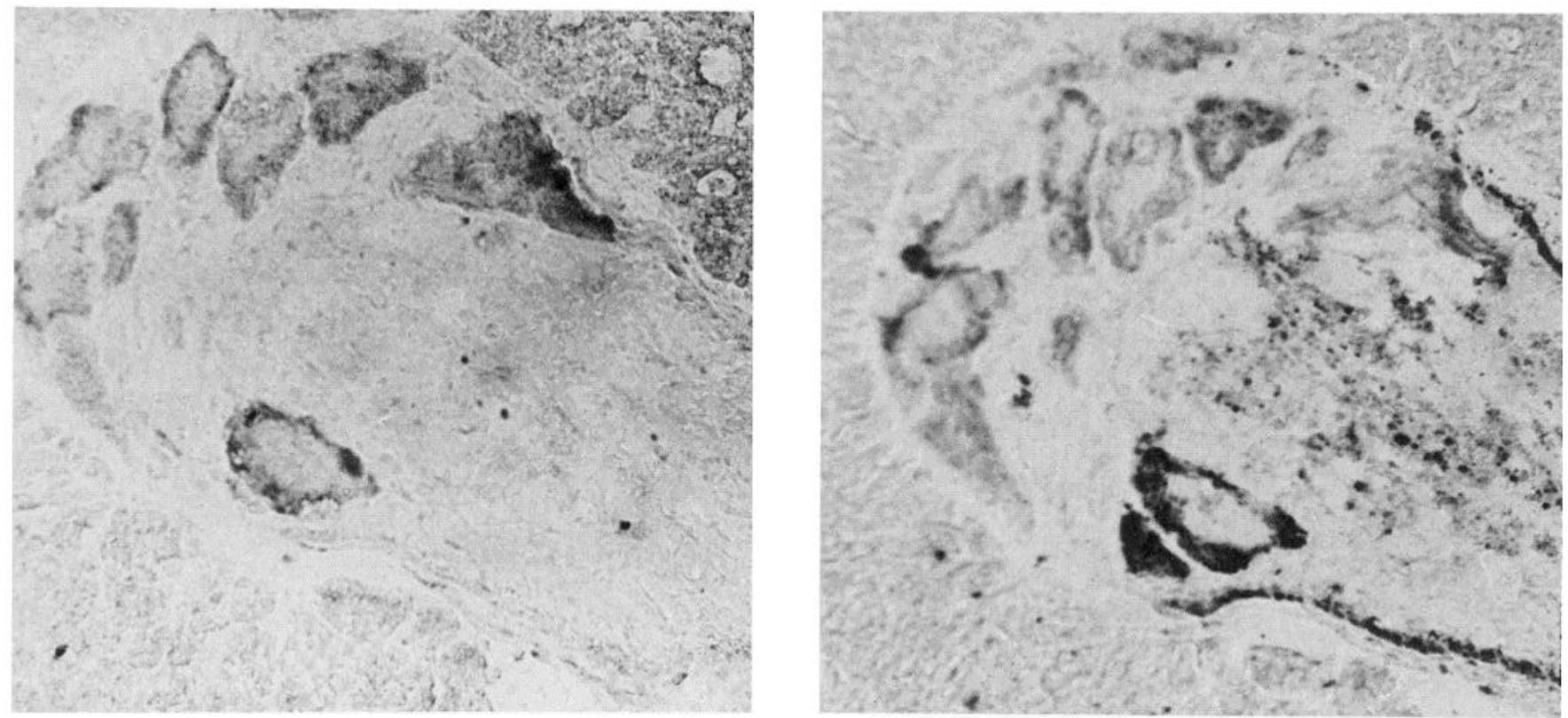

Figure 3. Adjacent horizontal sections of the light green cells of a snail captured during winter. The cells simultaneously display both enkephalin-like (a) and gastrin/CCK-like immunoreactivity $(b)$. Magnification $\times 256$.

at the periphery of the MLN (Fig. 2). In addition, strong gastrin/CCK. like immunoreactivity was noted in fibers running centrally in the $\mathrm{CC}$ and $\mathrm{MLN}$, in a portion of the BGC, and in scattered cell groups in the ventral lobe of the cerebral ganglion. Similar staining of spring snails revealed no gastrin/CCK-like immunoreactivity in the LGC and its peripheral terminals in the MLN but unchanged staining of the remaining structures. Experiments revealed that $A b .4562$ was unreactive toward Met- and Leu-enkephalin and endorphins, whereas $\mathrm{Ab} . \mathrm{KA}_{3}$ failed to react with gastrin-17, CCK-33, CCK-8, or caerulein (cf. Larsson and Stengaard-Pedersen, 1981, 1982). Staining of adjacent sections revealed that the subgroup of $B G C$ described above reacted with both $A b .4562$ and $A b$. $\mathrm{KA}_{3}$, whereas the cells detected in the ventral lobe of the cerebral ganglion stained either with $\mathrm{Ab} .4562$ or $\mathrm{Ab}$. $\mathrm{KA}_{3}$, but not with both. In snails captured during winter, the LGC and the peripheral terminals of the MLN stained for both gastrin/CCK-like immunoreactivity and for enkephalin-like immunoreactivity. Staining of adjacent sections revealed that the same subpopulation of LGC stained with both Ab. 4562 and Ab. $\mathrm{KA}_{3}$ (Fig. 3).

We used animals of different sizes captured during both spring and fall to see whether the change observed in the LGC and its MLN terminals was due to age or to seasonal variation. The size (shell-height) of the animals correlates with their age, which is also mirrored by the size and structure of the MDB. The MDB of young, sexually mature snails $(37 \mathrm{~mm})$ displays immunoreactivity in its cortical region (Table I), whereas in older animals (45 to $50 \mathrm{~mm}$ ), most immunoreactivity is collected in a medullary region. The type of immunoreactivity (enkephalin- or gastrin/CCK-like) detected in the LGC and its terminals depended solely upon the season and not upon the age of the animals. Incidentally, however, we found that the type of immunoreactivity in the CDC and their terminals, peripherally situated in the $C C$, as well as that of the MDB depended upon the age of the animals and not upon the season (Table I and Fig. 4). Thus, snails smaller than $40 \mathrm{~mm}$ displayed only enkephalin- and not gastrin/CCK-like immunoreactivity in the CDC and in the cortical region of the MDB, whereas in larger animals (42 to $52 \mathrm{~mm}$ ) gastrin/ CCK immunoreactivity occurred in the CDC, which now were devoid of enkephalin-like immunoreactivity (Fig. 4). Moreover, in such snails, the MDB contained both enkephalin- and gastrin/CCK-like immunoreactivity in its central (medullary) portion. Similarly, the CDC terminals in the CC were enkephalin-immunoreactive in young animals and gastrin/CCK-immunoreactive in old animals. In animals of inter- mediate age ( 40 to $41 \mathrm{~mm}$ ), the CDC and its CC terminals simultaneously contained both enkephalin- and gastrin/CCK-like immunoreactivity. Also in the cortical region of the MDB, colocalization of the two immunoreactivities was found in such animals (Table I).

In order to further delineate the identities of the peptides detected, cells staining with $\mathrm{Ab} .4562$, detecting the $\mathrm{C}$-terminal tetrapeptide of CCK-8, caerulein and gastrin were stained with Ab. 4698, detecting the $\mathrm{N}$-terminal tetrapeptide of CCK-8. As the cells were negative with $\mathrm{Ab} .4698$, we must conclude that they contain neither caerulein nor CCK-8-like peptides or that they store such peptides in a form making only their $\mathrm{C}$-terminal region but not $\mathrm{N}$-terminal region available for reaction with antibodies. The enkephalin-like immunoreactivity detected with $\mathrm{Ab} . \mathrm{KA}_{3}$ was also further analyzed with the aid of more selective antisera (Leu-enkephalin-Sepharose-absorbed Ab. $\mathrm{M}_{14}$ and the oxidation- $\mathrm{L}_{2}$-sequence). These antisera were potent in revealing the terminals and axons of the CDC and LGC, but they failed to react with the cell bodies. As $A b$. $K_{3}$ is more potent in detecting $\mathrm{C}$-terminally elongated enkephalin congeners, this result may indicate the existence of larger enkephalin precursor forms in the cell bodies and smaller enkephalin congeners in the terminals of the CDC and LGC.

\section{Discussion}

Our results show that both seasonal and age-dependent changes occur in neurosecretory cells in the central nervous system of $L$. stagnalis. Thus, the LGC, known to produce a body growthstimulating hormone, store enkephalin-like immunoreactivity during spring and gastrin/CCK-like immunoreactivity during fall. This pattern is observed both in the LGC cell bodies and in their terminals in the periphery of the median lip nerve, suggesting that the peptide immunoreactivities reflect secretory material. During a transitory period (winter), the LGC contained both enkephalin- and gastrin/ CCK-like immunoreactivity. In another group of neurons, the CDC, known to produce an ovulatory hormone, age-dependent changes were noted. Thus, in young animals, the CDC and their terminals in the cerebral commissure store enkephalin-like material. In snails of intermediate age, these cells store both enkephalin- and gastrin/ CCK-like immunoreactivity and, in larger animals, only gastrin/CCKlike immunoreactivity can be detected in the CDC. As shown in Table I, similar age-changes can be detected in the mediodorsal bodies of these snails. Both the CDC and the MDB have been 


\section{E NK}


CCK
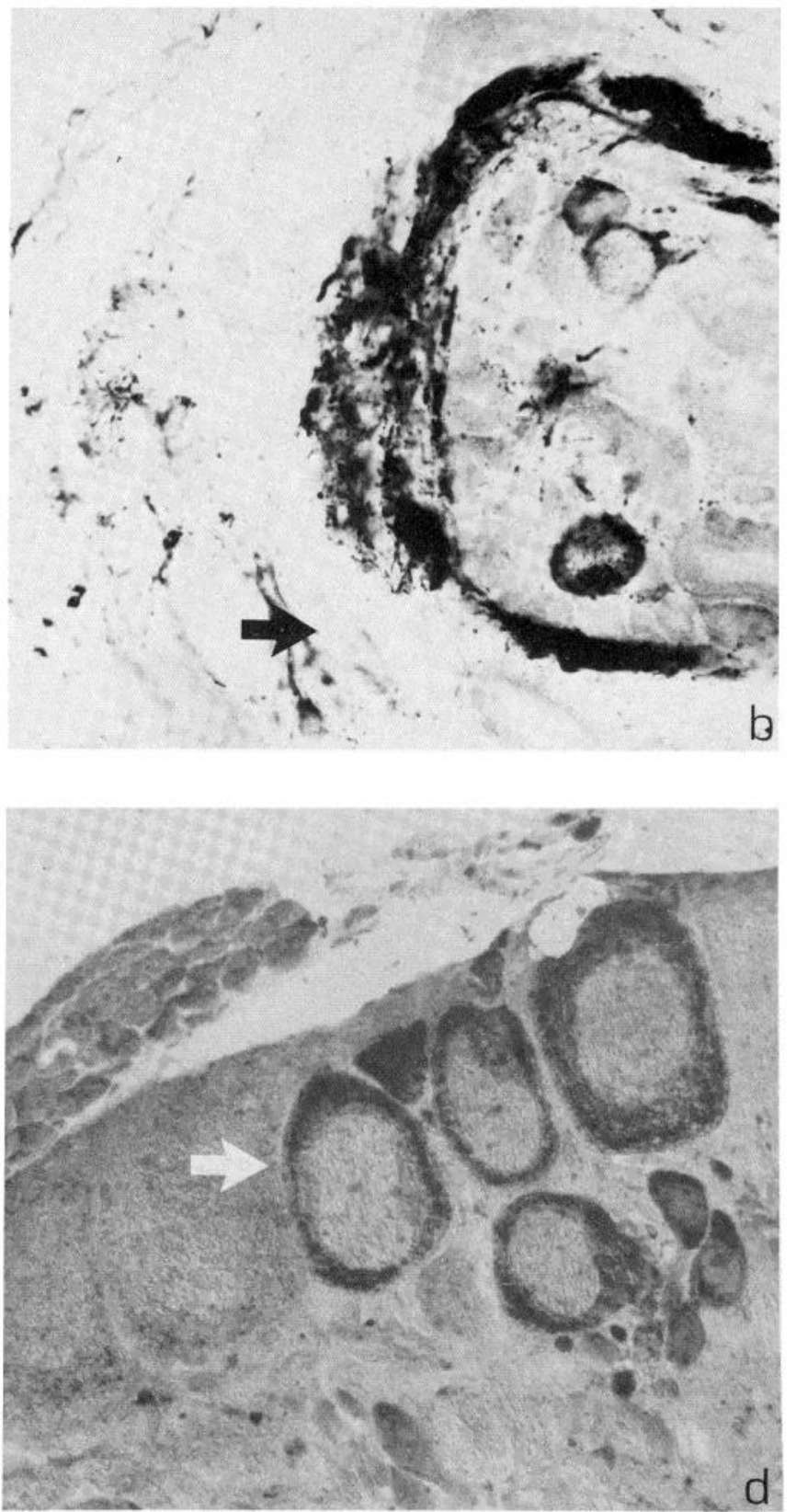

Figure 4. Adjacent horizontal sections showing immunoreactivity for enkephalin ( $a$ and $c)$ and gastrin/CCK $(b$ and $d)$ in young $(37 \mathrm{~mm})(a$ and $b)$ and older $(50 \mathrm{~mm})(c$ and $d$ ) animals. Note that the young snail only displays enkephalin-like immunoreactivity in the CDC, whereas the older animal only displays gastrin/CCK-like immunoreactivity in the CDC. Magnification $\times 400$.

proposed to produce hormones influencing the reproductive functions of the snails.

The molecular identities of the immunoreactivities detected are not yet fully established. Ab. 4562 detects a C-terminal tetrapeptide sequence common to gastrin, CCK, and caerulein and hence does not differentiate between these molecules. Caerulein has previously been suggested to represent an evolutionary precursor to gastrin and CCK, with which it shares the same biologically active C-terminal sequence (Larsson and Rehfeld, 1977). Radioimmunoassay studies on extracts of ganglia from garden snails have, upon gel chromatography, revealed C-terminal immunoreactivity to elute in a position between gastrin-17 and CCK-8 (Osborne, Cuello and Dockray,
1982). This material reacted well with an antiserum equipotent in detecting gastrin-17, CCK-8, and the common C-terminal tetrapeptide (CCK-4/G-4). However, other C-terminal antisera, reacting equally well with CCK- 8 and gastrin- 17 but less well with the Cterminal tetrapeptide, were less potent in revealing the material (Osborne et al., 1982). This agrees with our finding that Ab. 4698, which is specific for the N-terminal tetrapeptide of CCK-8 (and, hence, unreactive with gastrin but reactive with caerulein) fails to detect any neuronal cells in the cerebral ganglion. Hence, it is probable that the gastrin/CCK-like immunoreactivity reflects a yetunidentified peptide sharing its biologically active C-terminal region with gastrin, CCK, and caerulein. Since the sequence of G-4 is 
somewhat similar to the sequence of the molluscan cardioexcitatory peptide (FMRF-amide), cross-reactivity to this peptide must be.considered. However, in a previous study using an FMRF-amide-specific antiserum, no staining of the cells and terminals of the LGC or CDC was obtained (Schot and Boer, 1982). Similar studies performed in our laboratory confirm the absence of staining of these cell groups, although many other neuronal cell groups are stained with antiFMRF-amide serum. Hence, we must at present postulate that an unknown molluscan congener to gastrin and CCK is detected.

$\mathrm{Ab} . \mathrm{KA}_{3}$ detects a wide variety of opioid peptides, including $\mathrm{C}$ terminally elongated congeners of Met- and Leu-enkephalin ( $\beta$ endorphin, dynorphin, and $\alpha$-neoendorphin). More selective enkephalin antisera $\left(\mathrm{M}_{14}\right.$ and $\left.\mathrm{L}_{2}\right)$, however, document that molecules resembling true enkephalins occur in the axons and terminals of the CDC and LGC. So far, however, it is impossible to exclude the possibility that peculiar molluscan enkephalin congeners are being detected. Much evidence exists to indicate the presence of both opiate receptors and opioid peptides in snails (Haynes, 1980). Moreover, a functional role for an opiate system in snail thermal behavior was recently proposed (Kavaliers et al., 1983) and, very recently, three molluscan opioid peptides were sequenced and shown to be identical with Met-enkephalin, Leu-enkephalin, and Met-enkephalin-ArgPhe (Leung and Stefano, 1983). In a previous study, Met-enkephalinlike immunoreactivity was detected in the terminals of the CDC but not in the LGC (Schot et al., 1981). Our results confirm the localization to the CDC but, in addition, we find immunoreactivity in the LGC. This difference could theoretically bo accounted for by differing specificities of the antisera used, but it more probably relates to the fact that the study by Schot et al. (1981) used laboratory-bred and young snails, making it difficult to equate their findings to the annual cyclic changes and age changes observed in wild specimens.

Our observations show that season- and age-dependent changes in terms of immunoreactive peptides occur in identified neurosecretory neurons of the Lymnaea central nervous system. It is difficult to know whether the changes that we have registered reflect differences in synthesis (involving either gene expression, mRNA translation, or posttranslational processing), uptake, or release of these peptides. It would therefore be premature to attempt to correlate our findings to the functions of these identified neurons. Nevertheless, these findings indicate that neurosecretory neurons of invertebrates produce multiple immunoreactive peptides and that the intracellular amounts of these peptides vary with season and with age.

\section{References}

Buffa, R., J. A. Chayvialle, P. Fontana, L. Usellini, C. Capella, and E. Solcia (1979) Parafollicular cells of rabbit thyroid store both calcitonin and somatostatin and resemble gut $D$ cells ultrastructurally. Histochemistry 62 . 281-288

Eipper, B. A., and R. E. Mains (1978) Existence of a common precursor to $A C T H$ and endorphin in the anterior and intermediate lobes of the rat pituitary. J. Supramol. Struct. 8: 247-262.

Gerærts, W. P. M. (1976) Control of growth by the neurosecretory hormone of the light green cells in the freshwater snail Lymnaea stagnalis. Gen. Comp. Endocrinol. 29: 61-76.

Gerærts, W. P. M., and S. Bohlken (1976) The control of ovulation in the hermaphroditic freshwater snail Lymnaea stagnalis by the neurohormone of the caudodorsal cells. Gen. Comp. Endocrinol. 28: 350-357.

Gondman, R. H., J. N. Jacobs, P. C. Dee, and J. F. Habener (1982) Somatostatin-28 encoded in a cloned cDNA obtained from a rat medullary thyroid carcinoma. J. Biol. Chem. 257: 1156-1159.
Haynes, L. W. (1980) Peptide neuroregulators in invertebrates. Prog. Neurobiol. 15: 205-245

Hökfelt, T., O. J. Johansen, A. Ljungdahl, J. M. Lundberg, and M. Schultzberg (1980) Peptidergic neurons. Nature 284: 515-521.

Joosse, J. (1964) Dorsal bodies and dorsal neurosecretory cells of the cerebral ganglia of Lymnaea stagnalis L. Arch. Néerlandaises Zool. 16: $1-103$.

Joosse, J. (1975) Structural and endocrinological aspects of hermaphroditism in pulmonate snails, with particular reference to Lymnaea stagnalis $(L$.$) In:$ Intersexuality in the Animal Kingdom, R. Reinboth, ed., pp. 158-169, Springer Verlag, Berlin.

Kameda, Y., H. Oyama, and J. Horino (1984) Ontogeny of immunoreactive somatostatin in thyroid $\mathrm{C}$ cells from dogs and guinca pigs. Anat. Rec. 208: 89-101.

Kavaliers, M., M. Hirst, and G. C. Teskey (1983) A functional role for an opiate system in snail thermal behavior. Science 220: 99-101.

Larsson, L. -l. (1981a) Adrenocorticotropin-like and $\alpha$-melanotropin-like peptides in a subpopulation of human gastrin cell granules: Bioassay, immunoassay, and immunocytochemical evidence. Proc. Natl. Acad. Sci. U. S. A. $78: 2990-2994$

Larsson, L. -I. (1981b) Peptide immunocytochemistry. Prog. Histochem. Cytochem. 13: 1-85.

Larsson, L. -1. (1985) Distribution and morphology of somatostatin cells. In: Somatostatin, Y. C. Patel, ed., Plenum Press, New York, in press.

Larsson, L. -.., and L. Mørch-Jørgensen (1978) Ultrastructural and cytochemical studies on the cytodifferentiation of duodenal endocrine cells. Cell Tissue Res. 194: 79-102.

Larsson, L. -I., and J. F. Rehfeld (1977) Evidence for a common evolutionary origin of gastrin and cholecystokinin. Nature 269: 335-338.

Larsson, L. -1., and J. F. Rehfeld (1981) Pituitary gastrin occur in corticotrophs and melanotrophs. Science 213: 768-770.

Larsson, L. -I., and K. Stengaard-Pedersen (1981) Enkephalin/endorphinrelated peplides in an lrupyluric gastrin cells. J. Histochem. Cytochem. 29: 1088-1098.

Larsson, L. -.., and K. Stengaard-Pedersen (1982) Immunocytochemical and ultrastructural differentiation between Met-enkephalin-, Leu-enkephalin-, and Met/Leu-enkephalin-immunoreactive neurons of feline gut. J. Neurosci. 2: 861-878.

Leung, M., and G. B. Stefano (1983) Isolation of molluscan peptides. Life Sci. 33 (Suppl. 1): 77-80.

Osborne, N. N., A. C. Cuello, and G. J. Dockray (1982) Substance P and cholecystokinin-like peptides in Helix neurons and cholecystokinin and serotonin in a giant neuron. Science 216: 409-411.

Roubos, E. W., H. H. Boer, J. Vijdenes, and C. M. Mooren-van Delft (1976) Neurobiology of invertebrates. In Gastropoda Brain, J. Salanki, ed., pp. 101-109, Academic Press, N.Y.

Schot, L. P. C., and H. H. Bocr (1982) Immunocytochemical demonstration of peptidergic cells in the pond snail Lymnaea stagnalis with an antiserum to the molluscan cardioactive tetrapeptide FMRF-amide. Cell Tissue Res. 225: $347-354$.

Schot, L. P. C., H. H. Boer, D. F. Swaab, and S. van Noorden (1981) Immunocytochemical demonstration of peptidergic neurons in the central nervous system of the pond snail Lymnaea stagnalis with antisera raised to biological active peptides of vertebrates. Cell Tissue Res. 216: 273291

Snyder, S. H. (1980) Brain peptides as neurotransmitters. Science 209: 976983.

Sternberger, L. A. (1974) Immunocytochemistry, Prentice-Hall, Englewood Cliffs, NJ.

Vanderhaeghen, J. J., F. Lotstra, D. R. Liston, and J. Rossier (1983) Proenkephalin, Met-enkephalin, and oxytocin immunoreactivities are colocalized in bovine hypothalamic magnocellular neurons. Proc. Natl. Acad. Sci. U. S. A. 80: 5139-5143.

Wendelaar Bonga, S. E. (1970) Ultrastructure and histochemistry of neurose cretory cells and neurohaemal areas in the pond snail Lymnaea stagnalis (L.). Z. Zellforsch. 108: 190-224. 